\title{
Phytomass carbon pool of trees and forests in India
}

\author{
Meenakshi Kaul • G. M. J. Mohren • V. K. Dadhwal
}

Received: 30 October 2008 / Accepted: 13 October 2010 / Published online: 10 March 2011

(C) The Author(s) 2011. This article is published with open access at Springerlink.com

\begin{abstract}
The study reports estimates of above ground phytomass carbon pools in Indian forests for 1992 and 2002 using two different methodologies. The first estimate was derived from remote sensing based forest area and crown density estimates, and growing stock data for 1992 and 2002 and the estimated pool size was in the range 2,626-3,071 Tg C (41 to $48 \mathrm{Mg} \mathrm{C} \mathrm{ha}^{-1}$ ) and 2,660-3,180 Tg C (39 to $47 \mathrm{Mg} \mathrm{C} \mathrm{ha}^{-1}$ ) for 1992 and 2002, respectively. The second methodology followed IPCC 2006 guidelines and using an initial 1992 pool of carbon, the carbon pool for 2002 was estimated to be in the range of 2,668-3,112 $\mathrm{Tg} \mathrm{C}$ (39 to $46 \mathrm{Mg} \mathrm{C} \mathrm{ha}^{-1}$ ), accounting for biomass increment and removals for the period concerned. The estimated total biomass increment was about $458 \mathrm{Tg}$ over the period 1992-2002. Removals from forests include mainly timber and fuel wood, whereby the latter includes large uncertainty as reported extraction is lower than actual consumption. For the purpose of this study, the annual extraction values of 23 million $\mathrm{m}^{3}$ for timber and 126 million $\mathrm{m}^{3}$ for fuel wood were used. Out of the total area, 10 million ha are plantation forests with an average productivity $\left(3.2 \mathrm{Mg} \mathrm{ha}^{-1}\right.$ year $\left.^{-1}\right)$ that is higher than natural forests, a correction of $408 \mathrm{Tg} \mathrm{C}$ for the 10 year period was incorporated in total estimated phytomass carbon pool of Indian forests. This results in an estimate for the net sink of $4 \mathrm{Tg} \mathrm{C}$ year $^{-1}$. Both approaches indicate Indian forests to be sequestering carbon and both the estimates are in agreement with recent studies. A major uncertainty in Indian phytomass carbon pool dynamics is associated with trees outside forests and with soil organic carbon dynamics. Using recent remote-sensing based estimates of
\end{abstract}

M. Kaul (ه) · G. M. J. Mohren

Forest Ecology and Forest Management Group (FEM), Centre for Ecosystem Studies, Wageningen University, P. O. Box 47, 6700 AA Wageningen, The Netherlands e-mail: meenakshi.kaul72@gmail.com

G. M. J. Mohren

e-mail: frits.mohren@wur.nl

V. K. Dadhwal

National Remote Sensing Centre (NRSC), Indian Space Research Organisation, Hyderabad, India e-mail:vkdadhwal@nrsc.gov.in 
tree cover and growing stock outside forests, the estimated phytomass carbon pool for trees outside forests for the year 2002, is $934 \mathrm{Tg} \mathrm{C}$ with a national average tree carbon density of $4 \mathrm{Mg} \mathrm{Cha}^{-1}$ in non-forest area, in contrast to an average density of $43 \mathrm{Mg} \mathrm{C} \mathrm{ha}^{-1}$ in forests. Future studies will have to consider dynamics in both trees outside forests and soil for total terrestrial carbon dynamics.

\section{Introduction}

Tropical forests play an important role in the global carbon (C) cycle based both in terms of regulating the carbon flux between the biosphere and the atmosphere, and in terms of the amount of carbon stored. Indian forests are a major tropical forest ecosystem constituting nearly 67.83 million ha (Mha), $20.66 \%$ of the geographical area of country (329 Mha; FSI 2003). India's geographical area constitutes $2.4 \%$ of the world land area and about $2 \%$ of the global forests, while supporting $16 \%$ of the world's human population. Indian forests are known to be one of the richest in terms of vegetation types and species diversity. The revised forest type classification of Champion and Seth (1968) is the most widely used classification systems for Indian forests (Champion and Seth 1968). They classified the forests into five major groups based on climatic factors (Table 1). These major groups have been further divided into 16 type groups based on temperature and moisture contents. To cover the basic needs of the population, forests in India have been exploited not only for timber, fuel and fodder extraction but have also been subjected to overgrazing, shifting cultivation and conversion to non-forestry purposes such as roads, industries, mining, irrigation, hydro electric projects, transmission lines etc. thereby contributing to deforestation and degradation. It is estimated that between 1950 and 1980, the forest area converted for other purposes was 4.3 million ha in total, with an annual rate of 0.14 million ha (Lal 1989). For effective management of forest resources, the Forest Conservation Act (FCA) came into force in 1980, which prohibited conversion of forestland for other purposes without the prior approval of the Central Government. As a result, between 1980 and 2002 only 0.88 million ha of forest land was converted for other purposes, at an annual rate of 0.04 million ha (Forests and Wildlife Statistics of India 2004). Hence, the reduction in the rate of deforestation over the years was from 0.14 to 0.04 million ha annually.

According to the Forest Survey of India (FSI) assessment for 2002, the total forest cover in India is 67.83 Mha and the total recorded forest area 77.47 Mha $(23.57 \%$ of the country's geographical area) (FSI 2003). The difference in the two figures is due to the fact that the recorded forest area includes all lands statutorily notified as forest though they may not necessarily bear tree cover, whereas forest cover takes into account only those areas, which bear tree cover, and ignores those areas which may legally have the status of forest but have no trees. The total forest cover includes 38.77 Mha dense forest (about $57.18 \%$ of the total forest cover), 28.61 Mha (about $42 \%$ ) open forest and 0.45 Mha (0.14\%) mangroves (FSI 2003). The classification of density is based on crown cover viz., very dense forest (D1) with more than $70 \%$ canopy density, moderately dense forest (D2) with canopy density between $40 \%$ and $70 \%$ and open forest (D3) with canopy density between $10 \%$ and $40 \%$ (FSI 1995b). Similarly the total recorded forest area comprises of 39.99 Mha of Reserved Forest (51.6\%), 23.8 Mha of Protected Forest (30.77\%) and 13.64 Mha of Unclassed 
Table 1 Broad grouping of forest ecosystems in India and their distribution and extent

\begin{tabular}{|c|c|c|c|}
\hline Forest type & $\begin{array}{l}\text { Area } \\
\text { (million ha) }\end{array}$ & $\begin{array}{l}\% \text { of } \\
\text { forest area }\end{array}$ & Occurrence in states/UTs of India \\
\hline \multicolumn{4}{|l|}{ Tropical forests } \\
\hline $\begin{array}{l}\text { Tropical wet evergreen } \\
\text { forest }\end{array}$ & 4.5 & 5.8 & $\begin{array}{l}\text { Arunachal Pradesh, Assam, Karnataka, } \\
\text { Kerala, Mizoram, Manipur, Nagaland, } \\
\text { Tamil Nadu, Sikkim, Andaman and } \\
\text { Nicobar Islands and Goa }\end{array}$ \\
\hline $\begin{array}{l}\text { Tropical semi-evergreen } \\
\text { forest }\end{array}$ & 1.9 & 2.5 & $\begin{array}{l}\text { Assam, Karnataka, Kerala, Maharashtra, } \\
\text { Nagaland, Orissa, Tamil Nadu, } \\
\text { Andaman and Nicobar Islands and Goa }\end{array}$ \\
\hline $\begin{array}{l}\text { Tropical moist deciduous } \\
\text { forest }\end{array}$ & 23.3 & 30.3 & $\begin{array}{l}\text { Andhra Pradesh, Assam, Bihar, } \\
\text { Gujarat, Karnataka, Kerala, M.P., } \\
\text { Maharashtra, Manipur, Meghalaya, } \\
\text { Mizoram, Tripura, Nagaland, Orissa, } \\
\text { Tamil Nadu, U.P., West Bengal, } \\
\text { Andaman and Nicobar Islands, Goa } \\
\text { and Dadra and Nagar Havelli }\end{array}$ \\
\hline Littoral and swamp forest & 0.7 & 0.9 & $\begin{array}{l}\text { Andhra Pradesh, Gujarat, Maharashtra, } \\
\text { Orissa, Tamil Nadu, West Bengal, } \\
\text { Andaman and Nicobar Islands. }\end{array}$ \\
\hline $\begin{array}{l}\text { Tropical dry deciduous } \\
\text { forest }\end{array}$ & 29.4 & 38.2 & $\begin{array}{l}\text { Andhra Pradesh, Bihar, Gujarat, } \\
\text { Haryana, Himachal Pradesh, } \\
\text { Karnataka, Kerala, M.P., Maharashtra, } \\
\text { Jammu and Kashmir, Punjab, } \\
\text { Rajasthan, Tamil Nadu and U.P }\end{array}$ \\
\hline Tropical thorn forest & 5.2 & 6.7 & $\begin{array}{l}\text { Andhra Pradesh, Gujarat, Haryana, } \\
\text { Himachal Pradesh, Karnataka, M.P., } \\
\text { Maharashtra, Punjab, Rajasthan, } \\
\text { Tamil Nadu and U.P. }\end{array}$ \\
\hline Tropical dry evergreen forest & 0.1 & 0.1 & Andhra Pradesh and Tamil Nadu \\
\hline \multicolumn{4}{|l|}{ Sub-tropical forests } \\
\hline $\begin{array}{l}\text { Sub tropical broad leaved } \\
\text { hill forest }\end{array}$ & 0.3 & 0.4 & Assam and Meghalaya \\
\hline Sub tropical pine forest & 3.7 & 5.0 & $\begin{array}{l}\text { Arunachal Pradesh, Himachal Pradesh, } \\
\text { Jammu and Kashmir, Manipur, } \\
\text { Meghalaya, Nagaland, Sikkim, } \\
\text { Haryana, U.P. and Punjab }\end{array}$ \\
\hline $\begin{array}{l}\text { Sub tropical dry } \\
\text { evergreen forest }\end{array}$ & 0.2 & 0.2 & $\begin{array}{l}\text { Himachal Pradesh and Jammu } \\
\text { and Kashmir }\end{array}$ \\
\hline \multicolumn{4}{|l|}{ Temperate forests } \\
\hline $\begin{array}{l}\text { Montane wet temperate } \\
\text { forest }\end{array}$ & 1.6 & 2.0 & $\begin{array}{l}\text { Arunachal Pradesh, Karnataka, } \\
\text { Manipur, Nagaland, Sikkim } \\
\text { and Tamil Nadu }\end{array}$ \\
\hline $\begin{array}{l}\text { Himalayan moist } \\
\text { temperate forests }\end{array}$ & 2.6 & 3.4 & $\begin{array}{l}\text { Himachal Pradesh, Jammu and } \\
\text { Kashmir and Uttar Pradesh }\end{array}$ \\
\hline $\begin{array}{l}\text { Himalayan dry } \\
\text { temperate forests }\end{array}$ & 0.2 & 0.2 & $\begin{array}{l}\text { Jammu and Kashmir and } \\
\text { Himachal Pradesh }\end{array}$ \\
\hline \multicolumn{4}{|l|}{ Sub-alpine and alpine forests } \\
\hline Sub-alpine forest & & & Arunachal Pradesh and Himachal Pradesh \\
\hline Moist alpine-scrub & 3.3 & 4.3 & Jammu and Kashmir and Uttar Pradesh \\
\hline $\begin{array}{l}\text { Alpin } \\
\text { Total }\end{array}$ & 77 & 100 & nu and \\
\hline
\end{tabular}

Forest Survey of India, Ministry of Environment and Forests, Govt. of India 1995 
Forest (17.6\%). Reserved Forest is an area notified under the provisions of the Indian Forest Act (IFA) or the State Forest Acts (SFA) having a greater degree of protection. Protected Forests are also notified under the provisions of IFA and SFA but the restrictions are less severe. Unclassed Forest is an area recorded as forest but not included in reserved or protected forest category. The extent of recorded forest area and forest cover in India from 1992 to 2002 is given in Table 2.

The cumulative net carbon flux to the atmosphere due to deforestation and afforestation over the period 1880-1996 from Indian forests was estimated as 3.2 Pg C ( $1 \mathrm{Pg}=10^{15} \mathrm{~g}$; Chhabra and Dadhwal 2004). A number of recent studies have been published on the forest carbon pool (Ravindranath et al. 1997; Chhabra et al. 2002a; Haripriya 2000; Manhas et al. 2006; Lal and Singh 2000), as well as on emissions from deforestation and land use changes (Ravindranath et al. 1997; Chhabra and Dadhwal 2004; Kaul et al. 2009) in India. The phytomass carbon pool is based on growing stock from forest inventory as the primary data. Dadhwal and Nayak (1993) and Lal and Singh (2000), both used standard expansion and conversion factors, as prescribed in the Intergovernmental Panel on Climate Change (IPCC) guidelines for preparing national greenhouse gas inventories (IPCC 1995), while Ravindranath et al. (1997) and Chhabra et al. (2002a) used phytomass densities and biomass expansion factorsfor their estimates, and Manhas et al. (2006) ignored belowground biomass and branches, twigs and foliage etc.

Based on two commonly followed approaches (the ecologically based biomass density approach and the volume-based growing stock approach), the average forest carbon densities estimated in earlier studies were in the range of $30-68 \mathrm{Mg} \mathrm{C} \mathrm{ha}^{-1}$ (Table 3). However, there is wide variation in the estimated carbon pools and fluxes because of methodological differences, different sources of data, estimates for different years, as well as paucity of reliable country wide statistics and use of detailed global parameters for biomass estimates. The ecological studies based on biomass density approach adopted by Dadhwal and Nayak (1993) estimated the forest phytomass carbon pool as $1.99 \mathrm{Pg} \mathrm{C}$ (or $31 \mathrm{Mg} \mathrm{C} \mathrm{ha}^{-1}$ ) for the year 1985. Using the Remote Sensing (RS) based areas under different forest types and biomass densities for five crown cover levels, total (above and belowground) carbon pool for

Table 2 Recorded forest area and forest cover in India (1992-2002)

\begin{tabular}{|c|c|c|c|c|c|c|c|c|}
\hline \multirow[t]{2}{*}{ Year } & \multicolumn{4}{|c|}{ Recorded forest area (million ha) } & \multicolumn{4}{|c|}{ Forest cover (million ha) } \\
\hline & $\begin{array}{l}\text { Reserved } \\
\text { forests }\end{array}$ & $\begin{array}{l}\text { Protected } \\
\text { forests }\end{array}$ & $\begin{array}{l}\text { Unclassed } \\
\text { forests }\end{array}$ & $\begin{array}{l}\text { Total } \\
\text { forests }\end{array}$ & $\begin{array}{l}\text { Dense } \\
\text { forests }\end{array}$ & & $\begin{array}{l}\text { rove } \\
\mathrm{s}\end{array}$ & $\begin{array}{l}\text { Total } \\
\text { forests }\end{array}$ \\
\hline & $\begin{array}{r}41.65 \\
\quad(54.4\end{array}$ & $\begin{array}{r}22.33 \\
(29.1\end{array}$ & $\begin{array}{r}12.54 \\
(16\end{array}$ & $\begin{array}{r}76.52 \\
(23.2\end{array}$ & $\begin{array}{r}38.58 \\
(60\end{array}$ & (38 & $\begin{array}{l}0.45 \\
(0.71)\end{array}$ & $\begin{array}{l}63.96 \\
(19.46\end{array}$ \\
\hline 994 & $\begin{array}{l}41.65 \\
\quad(54.43)\end{array}$ & $\begin{array}{l}22.33 \\
\quad(29.18)\end{array}$ & $\begin{array}{l}12.54 \\
\quad(16.39)\end{array}$ & $\begin{array}{l}76.52 \\
\quad(23.28)\end{array}$ & $\begin{array}{l}36.74 \\
\quad(57.98)\end{array}$ & $\begin{array}{l}26.13 \\
\quad(41.26)\end{array}$ & $\begin{array}{l}0.48 \\
(0.76)\end{array}$ & $\begin{array}{l}63.34 \\
\quad(19.27)\end{array}$ \\
\hline 1997 & $\begin{array}{l}41.66 \\
(54.44)\end{array}$ & $\begin{array}{l}22.33 \\
(29.18)\end{array}$ & $\begin{array}{l}12.54 \\
(16.38)\end{array}$ & $\begin{array}{l}76.53 \\
(23.28)\end{array}$ & $\begin{array}{l}37.74 \\
\quad(59.21)\end{array}$ & $\begin{array}{l}25.51 \\
\quad(40.03)\end{array}$ & $\begin{array}{l}0.49 \\
(0.76)\end{array}$ & $\begin{array}{l}63.73 \\
(19.39\end{array}$ \\
\hline 2000 & $\begin{array}{l}42.33 \\
\quad(50.09)\end{array}$ & $\begin{array}{l}21.72 \\
(27.59)\end{array}$ & $\begin{array}{l}12.79 \\
(16.64)\end{array}$ & $\begin{array}{l}76.84 \\
\quad(23.38)\end{array}$ & $\begin{array}{l}41.40 \\
\quad(61.28)\end{array}$ & $\begin{array}{l}25.70 \\
\quad(38.30)\end{array}$ & $\begin{array}{l}0.45 \\
\quad(0.66)\end{array}$ & $\begin{array}{l}67.55 \\
(20.55)\end{array}$ \\
\hline 2002 & $\begin{array}{l}39.99 \\
\quad(51.61)\end{array}$ & $\begin{array}{l}23.84 \\
\quad(30.77)\end{array}$ & $\begin{array}{l}13.64 \\
(17.61)\end{array}$ & $\begin{array}{l}77.47 \\
(23.57)\end{array}$ & $\begin{array}{l}38.77 \\
\quad(57.16)\end{array}$ & $\begin{array}{l}28.61 \\
\quad(42.17)\end{array}$ & $\begin{array}{l}0.45 \\
(0.66)\end{array}$ & $\begin{array}{l}67.83 \\
\quad(20.66)\end{array}$ \\
\hline
\end{tabular}

FSI reports 1995a, b, 1997, 1999, 2001 and 2003. Values in parenthesis represent percentage of the total forests 
Table 3 Summary of estimated forest biomass and C-Pool for Indian forests

\begin{tabular}{|c|c|c|c|c|c|}
\hline Year & Methodology adopted & $\begin{array}{l}\text { Estimated } \\
\text { biomass } \\
(\mathrm{Tg})\end{array}$ & $\begin{array}{l}\text { Carbon } \\
\text { pool } \\
(\mathrm{Pg} \mathrm{C})\end{array}$ & $\begin{array}{l}\text { Carbon } \\
\text { density } \\
\left(\mathrm{Mg} \mathrm{C} \mathrm{ha}^{-1}\right)\end{array}$ & Ref. \\
\hline 1985 & $\begin{array}{l}\text { Field inventory of growing } \\
\text { stock and using single } \\
\text { conversion factor }\end{array}$ & 4,432 & 1.99 & 31 & {$[1]$} \\
\hline 1986 & $\begin{array}{l}\text { RS based forest area, biomass } \\
\text { densities from literature for } \\
\text { five crown cover levels for some } \\
\text { of the forest types and } \\
\text { extrapolating the same for } \\
\text { entire India }\end{array}$ & 8,372 & 4.18 & 65 & {$[2]$} \\
\hline $\begin{array}{c}1982 \text { and } \\
1991\end{array}$ & $\begin{array}{l}\text { Statewise RS based forest area, } \\
\text { field inventory based GS, } \\
\text { Biomass Expansion Factors } \\
\text { (BEF) for } 2 \text { crown density classes }\end{array}$ & $\begin{array}{l}7,960 \\
8,142\end{array}$ & $\begin{array}{l}3.98 \\
4.07\end{array}$ & $\begin{array}{l}62 \\
64\end{array}$ & {$[3]$} \\
\hline 1993 & $\begin{array}{l}\text { Statewise field inventory based } \\
\text { data on growing stock, } \\
\text { Biomass Expansion Factors } \\
\text { (BEF) for } 3 \text { crown density classes } \\
\text { and } 4 \text { forest categories }\end{array}$ & 8,685 & 4.34 & 68 & {$[4]$} \\
\hline 1993 & $\begin{array}{l}\text { Species wise forest inventory data, } \\
\text { mean wood density of various } \\
\text { strata and BEF ranging } \\
\text { from } 1.51 \text { to } 1.59 \text { for different } \\
\text { forest composition }\end{array}$ & 4,313 & 2.16 & 34 & {$[5]$} \\
\hline $\begin{array}{c}1984 \text { and } \\
1994\end{array}$ & $\begin{array}{l}\text { Strata wise estimation of GS } \\
\text { based on forest inventories, } \\
\text { thematic maps and vegetation } \\
\text { maps for different density } \\
\text { class. Wood biomass was further } \\
\text { estimated using specific } \\
\text { gravity and calculated } \\
\text { GS for each state }\end{array}$ & $\begin{array}{l}2,398 \\
2,395\end{array}$ & $\begin{array}{l}1.085 \\
1.083\end{array}$ & $\begin{array}{l}17 \\
17\end{array}$ & {$[6]$} \\
\hline $\begin{array}{c}1988 \text { and } \\
1994\end{array}$ & $\begin{array}{l}\text { District wise RS based forest } \\
\text { area, field inventory based } \\
\text { GS, BEF for } 2 \\
\text { crown density classes }\end{array}$ & $\begin{array}{l}7,742 \\
7,748\end{array}$ & $\begin{array}{l}3.871 \\
3.874\end{array}$ & $\begin{array}{l}60.5 \\
61\end{array}$ & [7] \\
\hline 1995 & $\begin{array}{l}\text { Stratum wise field inventory } \\
\text { of growing stock as reported } \\
\text { by FSI and standard } \\
\text { conversion factor as per } \\
\text { IPCC guidelines }\end{array}$ & 4,504 & 2.03 & 32 & {$[8]$} \\
\hline $\begin{array}{l}1992 \text { and } \\
2002\end{array}$ & $\begin{array}{l}\text { State-wise RS based forest area; } \\
\text { field inventory based GS; } \\
\text { state wise mean wood density } \\
\text { and } 2 \text { different values } \\
\text { of Mean BEFs calculated } \\
\text { from earlier studies }\end{array}$ & $\begin{array}{l}5,253 / 6,141 \\
\text { and } \\
5,321 / \\
6,359\end{array}$ & $\begin{array}{c}2.6 / 3.1 \text { and } \\
2.7 / 3.2\end{array}$ & $\begin{array}{c}41 / 48 \text { and } \\
39 / 47\end{array}$ & [9] \\
\hline
\end{tabular}

PgC $=10^{15}$ gC. [1] Dadhwal and Nayak (1993); [2] Ravindranath et al. (1997); [3] Dadhwal and Shah (1997); [4] Chhabra et al. (2002a); [5] Haripriya (2000); [6] Manhas et al. (2006); [7] Chhabra et al. (2002b); [8] Lal and Singh (2000); [9] this study 
the year 1986 was estimated as $4.18 \mathrm{Pg} \mathrm{C}\left(65 \mathrm{Mg} \mathrm{C}\right.$ ha $\left.^{-1}\right)$ (Ravindranath et al. 1997). Dadhwal and Shah (1997) estimated the state level forest phytomass C-pool based on two remote sensing based forest inventories, biomass expansion factor for two crown density, and estimates of growing stock. The results suggest that forest phytomass C-pool which was in the range of 3.68-4.27 Pg C in 1982 increased by 76-113 Tg C $\left(1 \mathrm{Tg}=10^{12} \mathrm{~g}\right)$ during the period 1982 and 1991 with an annual accumulation of 8.5-12.5 Tg C. The total phytomass C-pool of $4.34 \mathrm{Pg} \mathrm{C}\left(\right.$ about $68 \mathrm{Mg} \mathrm{C} \mathrm{ha}^{-1}$ ) for the year 1992-1993 was estimated using biomass expansion factors together with growing stock volume density, for three crown density classes and four major forest types (Chhabra et al. 2002a). Based on the stratum wise forest inventory data, mean wood density and biomass expansion factors, the above ground carbon pool was estimated to be $2.16 \mathrm{Pg} \mathrm{C}$ (about $34 \mathrm{Mg} \mathrm{C} \mathrm{ha}^{-1}$ ) for the year 1993 (Haripriya 2000). Manhas et al. (2006) used growing stock data and specific gravity to estimate the wood (stem or bole) biomass and carbon pool of Indian forests for 1984 and 1994. Total carbon stored in Indian forests (wood only) was 1.09 Pg C and 1.08 Pg C at a density of 24.9 and $24.5 \mathrm{Mg} \mathrm{Cha}^{-1}$ for 1984 and 1994 respectively. Chhabra et al. (2002b) estimated the total carbon pool of $3.87 \mathrm{Tg} \mathrm{C}$ (with an average density of $61 \mathrm{Mg} \mathrm{C} \mathrm{ha}^{-1}$ ) for the year 1994, using district level remote sensing based ground inventory on growing stock volume, and biomass expansion factors based on two crown density classes. Based on the stratum wise growing stock and using single expansion and conversion factors (as prescribed by IPCC) for the year 1995, Lal and Singh (2000) estimated forest carbon pool as $2.03 \mathrm{Pg} \mathrm{C}$ (about $32 \mathrm{Mg} \mathrm{C} \mathrm{ha}^{-1}$ ).

Forest plantations constitute a very important part of the forest resources. Due to varied agro-climatic conditions, a large number of species are planted. A lot of wood produced in India now comes from tree plantations established within and outside forest reserves. About 36 million ha of degraded and non-forest lands have been afforested during the period from 1951 to 2002, as shown in Fig. 1 (FSI 1999; Forests and Wildlife Statistics of India 2004). With agro forestry and policy changes

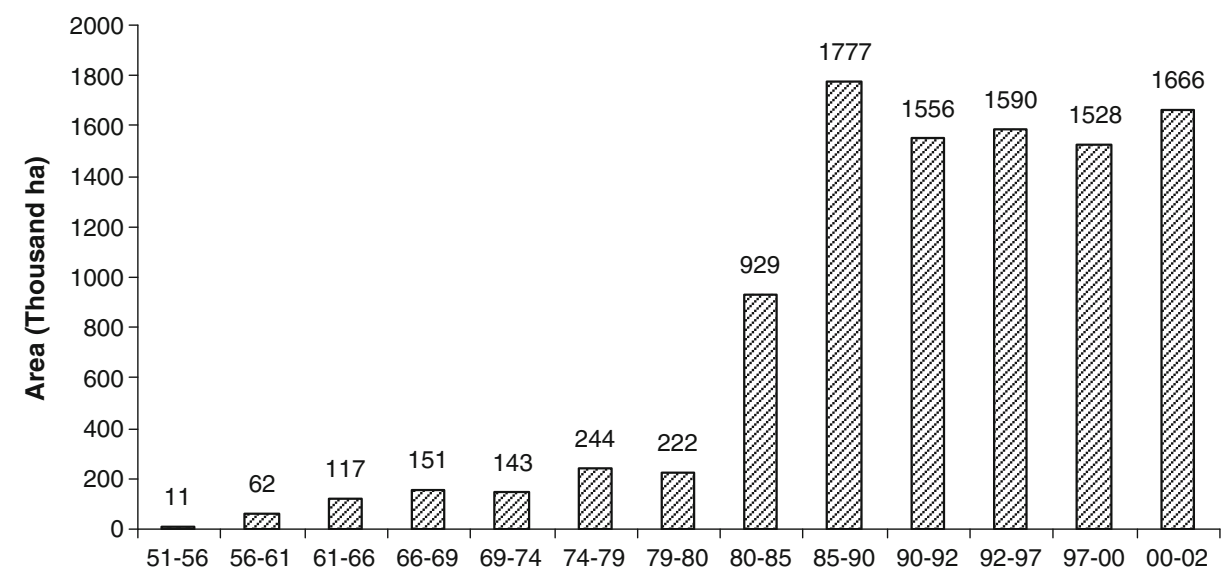

Plan Period

Fig. 1 The annual rate of plantation (1951-2002). Source: FSI (1999) and Forests and Wildlife Statistics of India (2004) 
in forest use, the role of trees outside forest is becoming increasingly important, but this has not been considered earlier in carbon studies.

In this paper, reported data on growing stock (FSI 1995a, b, 2003), forest area (FSI 1995a, b, 2003), estimated mean wood density and biomass expansion factor for individual states were synthesized to estimate phytomass carbon pool for 1992 and 2002 and the net carbon flux over the 10 year period. Next, the estimates for 2002 were compared with the results estimated by using an approach as recommended by IPCC (2006) guidelines, i.e., accounting for biomass increment and removal of wood from forests (IPCC 2006). In India, the volume of wood extracted for timber and fuel wood is highly debated as the actual consumption exceeds the recorded production (Haripriya 2003). Thus, for this approach, the assumed removal of wood from forests per year is subtracted only from the national estimate of phytomass Cpool. The parameters used for estimating biomass and carbon pools can further be used as inputs to models to estimate the net $\mathrm{C}$ flux from Indian forests due to land use changes, primarily deforestation.

\section{Materials and methods}

Forest Survey of India carries out assessment and monitoring of the forest cover of the country on a 2-year cycle and publishes the findings in the form of "State Forest Reports" (SFR) on biennial basis. The data for this study has been taken from FSI on growing stock and forest area under three crown density classes (D1, D2 and D3) for various States/Union Territories (FSI 1995a, b, 2003). To estimate the state-wise phytomass carbon pool for 1992 and 2002, the overall approach was to first estimate the state wise mean density of wood, mean biomass increment and mean biomass expansion factor using a change matrix.

State-wise phytomass C-pool for 1992 and 2002 were estimated using growing stock volume, strata-wise wood density and biomass expansion factors using the following equation:

$$
\mathrm{C}_{\mathrm{y}}=\left(\mathrm{V} \times \mathrm{D} \times \mathrm{F}_{\mathrm{j}} \times 0.5\right)
$$

where, $\mathrm{C}_{\mathrm{y}}(\mathrm{Pg} \mathrm{C})$ is the forest phytomass C-pool for year 1992 and 2002, V is the growing stock volume $\left(000^{\prime} \mathrm{m}^{3}\right.$ ) as reported by FSI for the year 1992 and 2002; D is the state-wise mean wood density $\left(\mathrm{Mg} \mathrm{per}^{3}\right)$ as estimated from Haripriya (2000) and $\mathrm{F}_{j}$ is the estimated biomass expansion factors for $(\mathrm{j}=1$ and 2 based on Haripriya 2000, and Chhabra et al. 2002a, respectively). The IPCC default value of 0.5 has been used for the carbon fraction of dry matter. In the second methodology based on IPCC 2006 guidelines, the 1992 estimate was retained as above and the phytomass Cpool for 2002 was estimated by considering biomass increment and biomass removal during 1992-2002. The changes in C-pool during the 10 year period were estimated using the gain and loss method (IPCC 2006).

$$
\Delta \mathrm{C}=\Delta C_{G}-\Delta C_{L}
$$

where, $\Delta \mathrm{C}$ is the annual carbon stock change in the pool $\left(\mathrm{Mg} \mathrm{C}\right.$ year $\left.{ }^{-1}\right), \Delta \mathrm{C}_{G}$ is the annual gain of carbon $\left(\mathrm{Mg} \mathrm{C}\right.$ year $\left.{ }^{-1}\right)$ and $\Delta \mathrm{C}_{L}$ is the annual loss of carbon $(\mathrm{Mg} \mathrm{C}$ year $^{-1}$ ). 
Gains can be attributed to growth (increase in biomass) and to transfer of carbon from one pool to another (e.g., transfer of carbon from the live biomass carbon pool to the dead organic matter pool due to harvest or natural disturbances). Losses can be attributed to transfers of carbon from one pool to another (e.g., the carbon in the slash during a harvesting operation is a loss from the above-ground biomass pool), or emissions due to decay, harvest, burning, etc. The carbon cycle includes changes in carbon stocks due to both continuous processes (i.e., growth, decay) and discrete events (i.e., disturbances like harvesting, insects, and fire). The parameters used for the estimation of phytomass carbon pool were estimated at the state level, whereas the biomass extraction and plantation figures given were applied at national level since state level data was not available. Factors such as shifting cultivation, natural decay of wood, forest fires and release of carbon from soil were not considered in this study.

Haripriya (2000) estimated the stratum wise biomass expansion factor and mean wood density $\left(\mathrm{Mg} / \mathrm{m}^{3}\right)$ for 21 forest strata. These values together with the growing stock are used to calculate the state wise mean density of wood (D) and mean biomass expansion factor $\left(\mathrm{F}_{1}\right)$ using a change matrix. Similarly, using growing stock volume density ( $\left.\mathrm{m}^{3} / \mathrm{ha}\right)$ and biomass density $(\mathrm{Mg} / \mathrm{ha})$ from Chhabra et al. (2002a), biomass expansion factor $\left(\mathrm{F}_{2}\right)$ was calculated state-wise separately for dense and open forests. The estimated values of annual increment, wood density, biomass expansion factor are given in Table 4.

In all the previous eight SFR assessment reports, forest cover was classified into 2 broad categories: dense forest and open forest. Dense forest included all lands with a forest cover of trees with a canopy density over $40 \%$ while open forest showed all lands with a forest cover of trees with a canopy density between 10 to $40 \%$. In the 2002 assessment report, the earlier category of dense forest was sub-divided into two classes "very dense forest" (where canopy density is above 70\%) and "moderately dense forest" (where canopy density lies between 40 and 70\%). The state-wise forest cover area and growing stock data pertaining to the study year 1992 and 2002 was obtained from state forest reports under three density classes D1 (canopy density more than 70\%), D2 (canopy density between 40\% and 70\% and D3 (canopy density between $10 \%$ and $40 \%$ ) (FSI 1995a, b, 2003). For the purpose of this study the area under D1 and D2 were added together under dense category.

Lal and Singh (2000) have published per hectare value of annual biomass increment for various natural forest types for the year 1995. The area occupied by 16 forest types in different states is reported in the state forest report (FSI 1987). Both these reported values were used to estimate the state-wise mean annual increment in $\mathrm{Mg}$ per ha. The mean annual biomass increment among the states varied between $0.67 \mathrm{Mg} \mathrm{ha}^{-1}$ for Rajasthan to $1.4 \mathrm{Mg} \mathrm{ha}^{-1}$ for Sikkim. The total biomass increment for the period 1992-2002 was estimated using forest area and the annual increment (dry matter, in $\mathrm{Mg} \mathrm{ha}^{-1}$ ) multiplied by number of years between two successive estimates for 4 time periods (i.e., 1994, 1997, 2000 and 2002). The 10-year biomass increment was estimated as $458 \mathrm{Tg}$ using Eq. 3. Arunachal Pradesh contributes maximum increment in biomass $(81 \mathrm{Tg}$ ) followed by Madhya Pradesh (75 $\mathrm{Tg}$ ) in the 10 year period:

$$
B=\sum_{i=1}^{27} \mathrm{~A} \times \mathrm{N} \times \mathrm{I}
$$


Table 4 Estimated state/union territory wise mean annual increment (I), ${ }^{a}$ mean wood density (D), ${ }^{\mathrm{b}}$ biomass expansion factor $\left(\mathrm{F}_{1}\right)^{\mathrm{c}}$ and $\left(\mathrm{F}_{2}\right)^{\mathrm{d}}$ and biomass increment $(\mathrm{BI})^{\mathrm{e}}$

\begin{tabular}{|c|c|c|c|c|c|c|c|c|}
\hline \multirow[t]{2}{*}{ States } & \multirow{2}{*}{$\begin{array}{l}\text { Mean } \\
(\mathrm{I}) \\
(\mathrm{Mg} / \mathrm{ha})\end{array}$} & \multirow{2}{*}{$\begin{array}{l}\text { Mean } \\
(\mathrm{D}) \\
\left(\mathrm{Mg} / \mathrm{m}^{3}\right)\end{array}$} & \multirow{2}{*}{$\begin{array}{l}\left(\mathrm{F}_{1}\right) \\
\text { total } \\
\text { forests }\end{array}$} & \multirow{2}{*}{$\begin{array}{l}\left(\mathrm{F}_{2}\right) \\
\text { dense } \\
\text { forests }\end{array}$} & \multirow{2}{*}{$\begin{array}{l}\left(\mathrm{F}_{2}\right) \\
\text { open } \\
\text { forests }\end{array}$} & \multicolumn{3}{|c|}{$\begin{array}{l}\text { Biomass increment (BI) } \\
\text { (Tg) 1992-2002 }\end{array}$} \\
\hline & & & & & & $\begin{array}{l}\text { Dense } \\
\text { forests }\end{array}$ & $\begin{array}{l}\text { Open } \\
\text { forests }\end{array}$ & $\begin{array}{l}\text { Total } \\
\text { forests }\end{array}$ \\
\hline Andhra Pradesh & 0.763 & 0.79 & 1.59 & 1.88 & 2.55 & 18.8 & 6.0 & 24.8 \\
\hline Arunachal Pradesh & 1.341 & 0.77 & 1.58 & 1.59 & 2.20 & 73.8 & 7.2 & 81.0 \\
\hline Assam & 0.974 & 0.79 & 1.58 & 1.51 & 1.89 & 14.4 & 4.1 & 18.5 \\
\hline Bihar & 0.675 & 0.71 & 1.58 & 2.20 & 2.94 & 9.4 & 3.6 & 13.0 \\
\hline Gujarat & 0.743 & 0.71 & 1.59 & 2.04 & 2.53 & 5.5 & 1.9 & 7.4 \\
\hline Haryana & 0.695 & 0.74 & 1.59 & 2.90 & 4.20 & 0.4 & 0.2 & 0.6 \\
\hline Himachal Pradesh & 1.271 & 0.47 & 1.52 & 1.11 & 1.58 & 12.1 & 2.0 & 14.1 \\
\hline $\begin{array}{l}\text { Jammu } \\
\text { and Kashmir }\end{array}$ & 1.434 & 0.43 & 1.51 & 1.11 & 1.15 & 15.9 & 5.6 & 21.5 \\
\hline Karnataka & 1.023 & 0.79 & 1.59 & 1.81 & 2.74 & 25.2 & 3.9 & 29.1 \\
\hline Kerala & 1.103 & 0.80 & 1.59 & 1.79 & 1.86 & 10.3 & 1.4 & 11.7 \\
\hline Madhya Pradesh & 0.730 & 0.75 & 1.59 & 2.11 & 2.55 & 60.7 & 14.4 & 75.2 \\
\hline Maharashtra & 0.784 & 0.70 & 1.58 & 1.97 & 2.77 & 21.3 & 6.0 & 27.4 \\
\hline Manipur & 1.060 & 0.76 & 1.57 & 1.66 & 2.63 & 6.1 & 4.9 & 11.0 \\
\hline Meghalaya & 0.838 & 0.76 & 1.53 & 1.42 & 1.90 & 4.5 & 3.5 & 8.0 \\
\hline Mizoram & 0.714 & 0.79 & 1.57 & 1.91 & 2.70 & 4.1 & 3.6 & 7.7 \\
\hline Nagaland & 1.245 & 0.80 & 1.58 & 1.61 & 2.30 & 6.0 & 4.5 & 10.5 \\
\hline Orissa & 0.758 & 0.72 & 1.59 & 2.03 & 2.69 & 20.5 & 6.2 & 26.8 \\
\hline Punjab & 0.695 & 0.70 & 1.57 & 3.51 & 4.35 & 0.5 & 0.2 & 0.8 \\
\hline Rajasthan & 0.667 & 0.76 & 1.59 & 3.33 & 4.58 & 3.0 & 2.7 & 5.7 \\
\hline Sikkim & 1.443 & 0.75 & 1.58 & 1.47 & 2.10 & 3.4 & 0.4 & 3.9 \\
\hline Tamil Nadu & 0.770 & 0.80 & 1.59 & 2.24 & 2.93 & 7.8 & 2.8 & 10.6 \\
\hline Tripura & 0.800 & 0.77 & 1.59 & 2.44 & 2.74 & 2.3 & 1.1 & 3.5 \\
\hline Uttar Pradesh & 1.065 & 0.63 & 1.56 & 1.45 & 2.32 & 25.8 & 4.9 & 30.7 \\
\hline West Bengal & 0.821 & 0.71 & 1.58 & 2.03 & 2.18 & 4.8 & 1.2 & 6.1 \\
\hline $\begin{array}{l}\text { Goa Daman } \\
\text { and Diu }\end{array}$ & 0.889 & 0.76 & 1.59 & 1.67 & 3.40 & 1.1 & 0.1 & 1.2 \\
\hline $\begin{array}{l}\text { Andaman } \\
\text { and Nicobar }\end{array}$ & 1.047 & 0.71 & 1.59 & 1.67 & 1.70 & 7.4 & 0.1 & 7.5 \\
\hline $\mathrm{D}$ and $\mathrm{N}$ Haveli & 0.800 & 0.69 & 1.59 & 2.25 & 3.84 & 0.1 & 0.0 & 0.1 \\
\hline All India & & & & & & 365 & 93 & 458 \\
\hline
\end{tabular}

${ }^{a}$ Derived from Lal and Singh (2000) and FSI (1995a, b)

${ }^{\mathrm{b}}$ Derived from Haripriya (2000) and FSI (1995a, b)

${ }^{\mathrm{c}}$ Derived from Haripriya (2000) and FSI (1995a, b)

${ }^{\mathrm{d}}$ Derived from Chhabra et al. (2002a) and FSI (1995a, b)

${ }^{\mathrm{e}}$ Derived from forest inventories

where $\mathrm{B}(\mathrm{Tg})$ is the total biomass increment, A (million ha) is the forest area for each state for 4 time periods, when $\mathrm{N}$ is the number of years between two successive estimates and $\mathrm{I}$ is the annual increment in biomass $\left(\mathrm{Mg} \mathrm{dm} \mathrm{ha}^{-1}\right)$ (Table 4).

Plantations are known to have higher biomass increment i.e., estimated national average being 3.2 Mg per hectare per year (Lal and Singh 2000). To account for higher rate of increment in plantation, national level C-pool was corrected by proportionate correction of increment to the plantation area of 10 Mha for 1992-2002. The plantation rate was corrected for short rotation species only where plantation 
area for last 10 years was used with the success rate of 0.70 . A plantation correction of $408 \mathrm{Tg}$ of carbon was added nationally while estimating the final carbon pool of Indian forests for the year 2002 using the following relation:

$$
\mathrm{P}_{c}=\mathrm{A}_{\mathrm{p}} \times\left(\mathrm{B}_{\mathrm{p}}-\mathrm{B}_{\mathrm{nf}}\right) \times \mathrm{n} \times 0.5
$$

where, $\mathrm{P}_{c}(\mathrm{Tg} \mathrm{C})$ is the correction for plantation pool; $\mathrm{A}_{\mathrm{p}}$ (million ha) is the plantation area in last 10 years with succession rate of $0.70 ; B_{p}$ and $B_{n f}$ are the biomass increments of plantation and natural forests respectively and $\mathrm{n}$ is the total number of years.

India's National Forest Policy (NFP 1988) aims at maintaining 33\% of country's geographical area under forest and tree cover. FSI has been assessing country's forest cover since the 1980's using data from remote sensing satellites on a 2-year cycle but tree cover due to a substantial number of trees not captured by the satellite data was estimated and reported for the first time in the 2001 assessment. This exercise, with much better inventory data on tree cover, has been continued in the 2003 assessment as well. It is important here to define "Tree Cover" and "Trees Outside Forests" (TOF). TOF means all tree crops growing outside recorded forest area. Whereas, tree cover, refers to the area covered by crown of trees that is too small to be delineated by digital interpretation of remote sensing data used for forest cover delineation. Thus, trees included in tree cover constitute only a part of TOF (FSI 2003). An estimated 2.68 billion trees outside forests contribute an equivalent additional area of 9.99 million ha. Thus, the total forest and tree cover of the country so estimated comes out to be 77.82 Mha constituting $23.68 \%$ of its geographical area (FSI 2003). The SFR 2003 reports the growing stock volume estimates for TOF at the state level. The total growing stock of wood is estimated to be 1,632 million $\mathrm{m}^{3}$ outside recorded forest area (FSI 2003). The phytomass carbon pool of TOF was estimated using the approach given in Eq. 1.

\section{Results and discussion}

\subsection{Forest cover change}

The forest cover as estimated using RS data in 1992 was 63.96 Mha and it increased to 67.83 Mha in 2002 (FSI 1995a, b, 2003). However crown density estimates indicate that the dense forest cover changed from 38.58 Mha in 1992 to 38.77 in 2002 and open forest cover changed from 24.93 Mha in 1992 to 28.61 Mha in 2002. Thus, indicating an overall higher proportional contribution of open forest category. A study of net change in forest cover between the year 1992 and 2002 (Table 2) shows a deforestation of 0.79 Mha and afforestation of 4.64 Mha thereby, increasing the total forest cover by 3.87 Mha. Whereas, inter-comparison of forest covers at the district level, in different states highlights that overall large patches of forest cover has increased (about 0.7 Mha per year) and also about 0.3 Mha per year of deforestation has taken place.

The state-wise analysis of forest cover change indicates that for states of Assam, Gujarat, Himachal Pradesh, Jammu and Kashmir, Karnataka, Sikkim and Madhya Pradesh decreased dense forest cover is accompanied by increased open forest. 
Contrary to this, in Manipur, Meghalaya, Mizoram, Nagaland and Tripura decreased open forest cover is complemented by increased dense forest cover. The states of Bihar, Haryana, Kerala, Maharashtra, Orissa, Punjab, Rajasthan, Tamil Nadu, Uttar Pradesh, West Bengal and Goa, Daman and Diu showed an increase in both categories. Madhya Pradesh and Andhra Pradesh are the two main states showing maximum reduction in the forest cover between 1992 and 2002. The presence of economical species such as Shorea robusta Gaertn.f, Madhuca indica J.F. Gmel, Emblica officinalis Gaertn., Terminalia alata Heyne ex Roth, Borassus flabellifer L. etc is the major cause of disturbance in these forests (Manhas et al. 2006).

\subsection{Growing stock}

The growing stock estimates for 1992 and 2002 by FSI are 4,741 million $\mathrm{m}^{3}$ and 4,782 million $\mathrm{m}^{3}$. The growing stock data for two periods were independently used with mean wood density (D) and biomass expansion factor $\left(\mathrm{F}_{1} / \mathrm{F}_{2}\right)$ for two estimates of phytomass C-pool each for 1992 and 2002. Using directly 1992 and 2002 growing stock data and conversion factors (approach 1) the phytomass C-pool in 1992 was estimated as 2,626 and 3,071 Tg C and in 2002 was estimated as 2,660 and 3,180 Tg C. This suggests nationally phytomass C-pool was a net sink in the range of 34-109 Tg C or 3.4-10.9 $\mathrm{Tg} \mathrm{C}$ year $^{-1}$ for the 10-year period. Further, the predicted phytomass carbon pool for 2002, using the IPCC 2006 methodology based on the increment and removal approach (approach 2), was estimated as 2,668 and 3,112 $\mathrm{Tg} \mathrm{C}$ with an average density of $43 \mathrm{Mg} \mathrm{Cha}{ }^{-1}$. Comparison of the phytomass C-pool estimates from both the approaches suggest that Indian forests are sequestering carbon and indicate a small annual national sink of $4 \mathrm{Tg} \mathrm{C} \mathrm{year}^{-1}$ (or $42 \mathrm{Tg} \mathrm{C}$ in 10 -year period). Despite the marginal decrease in the percentage of dense forest cover between 1992 and 2002, the growing stock has registered a slight increase during this period. The increase in growing stock may be attributed to the improvement in density, without increase in area.

\subsection{Biomass expansion factors}

Biomass expansion factors were used to convert stand volume to aboveground biomass and account for the non-commercial components such as branches, twigs, bark, stumps and foliage. Brown et al. (1989) and Hall and Uhlig (1991) report these factors to be in the range 1.14-1.6. However, Brown et al. (1989) related biomass expansion factors to volume and density and the same approach was used in Chhabra et al. (2002a), to convert growing stock in three density classes to an estimate for the forest C-pool. Haripriya (2000) used regression equations for species such as Teak (Tectona grandis Linn f.), Sal (Shorea robusta Gaertn.f.) and Chir pine (Pinus Roxburghii). The biomass expansion factors used were 1.59 for broad-leaved species, 1.51 for conifers and 1.55 for hardwoods mixed with conifers, similar to Hall and Uhlig (1991) and Brown et al. (1989). Biomass expansion factors were also estimated using the ratio of biomass density and growing stock volume density for three crown density classes of forest cover in each state as published in Chhabra et al. (2002a). The latter is based on log relation between growing stock volume density and biomass expansion factor (Brown et al. 1999). The approach of using density dependent biomass expansion factors from (Chhabra et al. 2002a) provided 
conversion factors in range of 1.1-2.4 for dense forests and 1.15-4.6 for open forests. The biomass expansion factors used in this study are within the range as proposed by earlier authors for tropical forests. The results from both the approaches strongly suggest that accumulation in aggrading forest in the study period have resulted in an increase in the phytomass carbon pool and furthermore indicate an annual sink of $4 \mathrm{Tg} \mathrm{C}$ at the national level. For India, Ravindranath et al. (1997) has estimated a marginal net sequestration of $5 \mathrm{Tg} \mathrm{C}$ for the reference year 1986. However, there are additional factors mentioned below that need to be considered before the net carbon balance for Indian forests and trees can be derived.

\subsection{Wood extraction}

In India, the volume of reported extraction of timber and fuel wood from forests is much lower than the actual consumption (Haripriya 2003). There are different estimates for fuel wood such as 235 million $\mathrm{m}^{3}$ per year (Ravindranath et al. 1997), 303 million $\mathrm{m}^{3}$ for 1996 (FSI 1996), 297 million $\mathrm{m}^{3}$ for 2000 (FAO 2002). Similar to varying estimates on fuel wood consumption, considerable difference of opinion on what fraction comes from forests exists. The National Sample Survey Organisation (NSSO) of the Ministry of Statistics and Programme Implementation estimated that annual requirement of fuel wood is $201 \mathrm{Tg}$ or 251 million $\mathrm{m}^{3}$, out of which approximately $51 \%$ (103 Tg) comes from forests (including plantation) and rest $49 \%$ $(98 \mathrm{Tg}$ ) from farm forestry and other wooded lands outside forests. Most of the fuel wood studies conducted in India focused on the consumption aspect rather than the supply and source aspect. Since no reliable information is available on production and consumption of wood from forests, the total annual demand of wood is between 324-434 million $\mathrm{m}^{3}$, where as the total sustainable availability of wood from all sources (public and private) is only 127 million $\mathrm{m}^{3}$ per year (www.un.org). For the purpose of this study, it was assumed that approximately 23 million $\mathrm{m}^{3}$ of timber and 126 million $\mathrm{m}^{3}$ of fuel wood were extracted from the Indian forests annually (Haripriya 2001). The estimated total phytomass carbon removed from the forests was 59.6 Tg C per year or $596 \mathrm{Tg} \mathrm{C}$ in the 10 year period from 1992 to 2002, which was subtracted from the national total only. This approach has not been adopted in earlier studies as availability of reliable data is limited. Thus, the projected phytomass carbon pool for the year 2002 was in the range 2,668 $\mathrm{Tg} \mathrm{C}-3,112 \mathrm{Tg} \mathrm{C}$ with an average carbon density of $43 \mathrm{Mg} \mathrm{C} \mathrm{ha}^{-1}$ using the increment and removal approach.

\subsection{Role of trees outside forests}

TOF include trees in cities, on farms, along roads, canals, railway tracks and in many other locations which by definition are not forests. Trees outside forests have been making a major contribution in meeting the needs of timber and fuel wood. The total growing stock of wood in India is estimated to be 6,414 million $\mathrm{m}^{3}$ comprising 4,782 million $\mathrm{m}^{3}$ inside forests and 1,632 million $\mathrm{m}^{3}$ outside recorded forest area (FSI 2003). Maximum growing stock in TOF is observed in Andhra Pradesh followed by Maharashtra and Gujarat. Most of the studies conducted so far have not considered the role of trees outside forests in carbon balance. Trees outside forests store about $934 \mathrm{Tg} \mathrm{C}$ or $4 \mathrm{Mg} \mathrm{C} \mathrm{ha}^{-1}$, in addition, to the Indian forests. 
3.6 Role of soil as deforestation area is large

Soil organic carbon is the largest terrestrial carbon reservoir. Approximately $40 \%$ of the global carbon inventory resides in forest ecosystems and dynamics of forest soil organic carbon has significant implications to global carbon budget. Although there are some recent studies on Indian forest phytomass C-pool (Ravindranath et al. 1997; Chhabra et al. 2002a), litterfall (Dadhwal et al. 1997) and soil organic carbon (Chhabra et al. 2003) but more refined and accurate estimates of soil organic C-pool in different Indian forest types are required for computing soil carbon cycle changes due to deforestation in India.

\subsection{Role of stored wood products}

Carbon is released from harvested materials at all stages of progressing, product use and final disposal. Due to burning of fuel wood, $90 \%$ of the harvested carbon from forests is emitted in the first year itself, and during the production process, $9 \%$ is lost as process energy (Haripriya 2001). Of the large mass of carbon harvested in India in 1994 , only $0.8 \%(515 \mathrm{Gg} \mathrm{C}$ out of $68,880 \mathrm{Gg} \mathrm{C})$ is remaining in the wood products in use at the end of 100 years. As fuel wood is the main source of energy in India, the amount of carbon stored into wood products is very small. Improving the processing efficiencies and increasing the durability of small and medium lifespan wood products and providing sustainable sources of energy in order to substitute for unit of carbon emitted due to burning of fossil fuels can increase the carbon sequestration into wood products.

\subsection{Carbon loss due to forest degradation}

Deforestation and other changes in land use cause significant exchanges of carbon between the land and the atmosphere. In addition to carbon release from deforestation or clear cutting, degradation of existing forests also contributes to carbon release from grazing, fire, death due to disease and pests, illegal removal of timber, nonsustainable harvest of firewood or timber, etc. Evidence of this is available from various studies (Manhas et al. 2006; Ravindranath et al. 1997; Haripriya 2003; Chhabra and Dadhwal 2004; Haripriya and Atkinson 2006; Kaul et al. 2009). Ravindranath et al. (1997) reported that for the reference year 1986, a total of 27.6 Tg C is emitted from the Indian forests annually as a result of deforestation and $12.87 \mathrm{Tg} \mathrm{C}$ from degraded forests. Manhas et al. (2006) estimated that between 1984 and 1994 about 17.22 $\mathrm{Tg}$ wood biomass and 10.69 $\mathrm{Tg} \mathrm{C}$ was removed at the rate of $1.72 \mathrm{Tg}$ year $^{-1}$ and $1.07 \mathrm{Tg} \mathrm{C}$ year $^{-1}$ respectively, from the North-Eastern states. The cumulative area subject to shifting cultivation in North-Eastern states during the period from 1987 to 1997 was 1.73 Mha (FSI 1999). FSI (2003) assessment reveals that the practice of shifting cultivation in North-Eastern states has affected forest cover to an extent of 0.55 Mha between the period 2001-2003. Maximum effect due to shifting cultivation was observed in Nagaland, followed by Arunachal Pradesh, Manipur, Mizoram and Meghalaya. However, due to rapid regeneration of abandoned shifting cultivation areas, where vegetation comes up quickly, the net change in forest cover of these states between 2001 and 2003 assessment showed a net gain of 0.39 Mha (FSI 2003). In India, grazing and forest fires are one of the factors increasingly contributing in 




Fig. 2 Comparison of state-level forest phytomass C density estimates for 2002 with Richards and Flint (1994) estimate for 1980 (open square), Chhabra et al. (2002b) for 1988 (asterisk) and Chhabra and Dadhwal (2004) for 1993 (filled triangle)

the degradation process. On an average, 54.7\% of forests are affected by fires and $72.1 \%$ of the forest area is subjected to grazing (Manhas et al. 2006). Kaul et al. (2009) estimated that the annual change in C stocks in biomass due to forest land conversion to cropland and waste land was 9.4 Tg C during 1982-1992 and 3.02 Tg C during the period from 1992-2002.

The phytomass C-pool estimates are associated with significant uncertainties due to deficiencies in data, volume biomass conversion approach and the extent of the effect of human activity on ecosystems and environment, because many ecological processes depend on the carbon cycle. Comparison of our state level forest phytomass C-pool estimates with earlier studies is shown in Fig. 2. The comparison shows that the earlier studies have higher estimates of the phytomass carbon density than ours. This may be due to estimation of only wood biomass in our study or due to higher percentage of degraded forest cover in India. Chhabra and Dadhwal (2004) used the growing stock volume density with an additional biomass expansion factor for bamboo. This estimate was $\sim 21 \%$ higher than the present estimate. The correlation coefficient, $\mathrm{r}$ was $0.85,0.83$ and 0.90 with Richards and Flint (1994) estimate for 1980; Chhabra et al. (2002b) for 1988, and Chhabra and Dadhwal (2004) for 1993.

\section{Conclusion}

In spite of the fact that biomass demands and pressure on Indian forests continue to grow because of increasing population, the conversion of forest lands for other uses 
has actually declined since 1980 . This is mainly due to enforcement and effective implementation of measures to control deforestation of our natural forests and ensure rehabilitation of major forest areas.

The results indicate that the predicted phytomass carbon pool for 2002, using the IPCC 2006 methodology based on the increment and removal approach, was in the range 2,668-3,112 $\mathrm{Tg} \mathrm{C}$ with an average density of $43 \mathrm{Mg} \mathrm{C}^{-1}$ and using directly 2002 growing stock data and conversion factors it was estimated as 2,660-3,180 Tg C with an average density of $43 \mathrm{Mg} \mathrm{Cha}^{-1}$. Thus, it is concluded that Indian forests are sequestering carbon when the phytomass C-pool estimates of 1992 and 2002 are compared. The results from both the approaches strongly suggest that accumulation in aggrading forest in the study period have resulted in an increase in the phytomass carbon pool and indicate a small annual sink nationally of $4 \mathrm{Tg} \mathrm{C}$ year $^{-1}$. The estimated C-pool for trees outside forests is $934 \mathrm{Tg} \mathrm{C}$ indicating a national average tree $\mathrm{C}$ density of $4 \mathrm{Mg} \mathrm{C}^{-1}$ in non-forest area in contrast to an average density of $43 \mathrm{Mg} \mathrm{C} \mathrm{ha}^{-1}$ in forests. However, there are additional factors mentioned earlier that also need to be considered before net carbon balance for Indian forests and trees is estimated. It is clear from the entire national, state and district level studies conducted so far that there are several fuel wood sources but the exact contribution from each source is not known. A major segment of the rural population gathers fuel wood and other bio-fuels free of cost and therefore accurate records of removal and consumption are not maintained. Since the per capita consumption of fuel wood is a dynamic entity and varies in time and space, per capita estimates of rural and urban fuel wood consumption are also not accurate. Moreover, there exists a large amount of wood resource outside the forests and accurate information about these trees is a pre-requisite for their proper management.

In spite of high pressure, forest biomass currently is not a very large source of carbon dioxide in India. This has also been concluded in studies such as Ravindranath et al. (1997) and Chhabra et al. (2002b). This is also supported by Kauppi et al. (2006) who have found forests to be sequestering carbon in many parts of the world. Since deforestation continues and soil also continues to lose $\mathrm{C}$, the net $\mathrm{C}$ release could be higher. However in 10-year period, 3.85 Mha have been added, 0.79 Mha is deforestation while unrecorded extraction could be much higher. Thus, model studies and spatial analysis is needed to estimate source and sink of carbon with greater confidence. Our results provide an improvement over the previous estimates as they include biomass increment and removal at the national level. The mismatch between the periods of image acquisition for remote sensing based inventories and field inventory of growing stock by FSI may introduce uncertainty in the carbon estimates. Thus, comparable year to year growing stock estimates are not available and constant carbon density for open and dense forest category is usually assumed. However, due to continuous harvest or deforestation as well as afforestation, constant density is not likely to hold.

The Ministry of Environment and Forests (MoEF 1999) estimates total plantation area, i.e., as forests, wastelands, village commons, and road/canal side and farmers lands. The road/canal side and farmers land plantation will be reflected in trees outside forests. In addition due to short rotation plantation (7-10 years), species are clear felled and the area is replanted. In cumulative area of plantations, replanted areas are counted doubly and areas of failed plantations are also included. Uncertainty therefore exists in the actual area of plantations. Chhabra et al. (2002b) 
therefore, suggested that if estimates are obtained at district level/ grid wise more refined numbers would be generated. Direct use of plantation area would give rise to larger overestimates and we aim to produce conservative estimate in our study.

The use of different biomass expansion factors is another major contributor to the uncertainty in phytomass carbon estimates. Results indicate that use of common BEF's can underestimate the above ground biomass as Brown et al. (1989) have demonstrated BEF is related to growing stock volume density. Also using different biomass expansion factors for dense and open forest categories resulted in low and high forest phytomass carbon estimates, indicating that many states which have large forest area in dense category the carbon densities are low (Dadhwal and Shah 1997). This reflects the large pressure and use of forests in India. The biomass expansion factors used for our study are species based in dense and open density classes of Indian forest types. It is required to develop expansion factors based on Indian data to represent various forest types or species specific in order to reduce the uncertainties and improve the estimates of forest phytomass C-pools and net $\mathrm{C}$ flux in Indian forests. Forest carbon density changes as a result of succession, growth, harvesting, and clearing of forests for non-forest purposes and natural disturbances like fires, insect and pest outbreaks or changes in climate. In a developing country like India, because of increasing population density, forest degradation will continue thereby reducing forest $\mathrm{C}$ density and releasing carbon into the atmosphere. However, proper management of degraded forests will result in significant increase in carbon sequestration by these forests.

Acknowledgements The authors are glad to acknowledge the untiring help rendered by late Shri. O.N. Kaul (Retd. Chief Conservator of forests) in locating various sources of data. Authors would also like to thank Dr. Alok Saxena (Joint Director), Forest Survey of India (FSI) for providing the relevant data on forest inventories.

Open Access This article is distributed under the terms of the Creative Commons Attribution Noncommercial License which permits any noncommercial use, distribution, and reproduction in any medium, provided the original author(s) and source are credited.

\section{References}

Brown S, Gillespie AJR, Lugo AE (1989) Biomass estimation methods for tropical forests with application to forest inventory data. For Sci 35:881-902

Brown SL, Schroeder P, Kern JS (1999) Spacial distribution of biomass in forests of the eastern USA. For Ecol Manag 123:81-90

Champion HG, Seth SK (1968) A revised forest types of India. Manager of Publications, Government of India, Delhi

Chhabra A, Dadhwal VK (2004) Assessment of major pools and fluxes of carbon in Indian forests. Climatic Change 64:341-360

Chhabra A, Palria S, Dadhwal VK (2002a) Growing stock based forest biomass estimate for India. Biomass Bioenergy 22:187-194

Chhabra A, Palria S, Dadhwal VK (2002b) Spatial distribution of phytomass carbon in Indian forests. Glob Chang Biol 8:1230-1239

Chhabra A, Palria S, Dadhwal VK (2003) Soil organic carbon pool in Indian forests. For Ecol Manag 173:187-199

Dadhwal VK, Nayak SR (1993) A preliminary estimate of biogeochemical cycle of carbon for India. Sci \& Cult 59:9-13 
Dadhwal VK, Shah AK (1997) Recent changes (1982-1991) in forest phytomass carbon pool in India estimated using growing stock and remote sensing based forest inventories. J Trop For 13: 182-188

Dadhwal VK, Shukla N, Vora AB (1997) Forest litter fall in India: a review and estimate of litter fall carbon flux. Indian For 123(1):45-52

FAO forest products yearbook database 2002. Role of wood energy in Asia. www.fao.org/docrep/ w7519e

Forests and Wildlife Statistics of India (2004) National afforestation and eco-development board. Ministry of Environment and Forest, Govt. of India

FSI (1987) State of the forest report 1987. Forest survey of India, ministry of environment and forest. Govt. of India, Dehradun

FSI (Forest Survey of India) (1995a) Extent, composition, density of growing stock and annual increment of India's forests. FSI, Dehradun

FSI (1995b) State of the forest report 1995. Forest Survey of India, Ministry of Environment and Forest. Govt. of India, Dehradun

FSI (1996) Fuel wood, timber and fodder from forest of India. Forest Survey of India, Dehradun

FSI (1997) State of the forest report 1997. Forest Survey of India, Ministry of Environment and Forest, Govt. of India, Dehradun

FSI (1999) The state of the forest report. Forest Survey of India, Ministry of Environment and Forest, Govt. of India, Dehradun

FSI (2001) State of the forest report 2001. Forest Survey of India, Ministry of Environment and Forest, Govt. of India, Dehradun

FSI (2003) State of the forest report 2003. Forest Survey of India, Ministry of Environment and Forest, Govt. of India, Dehradun

Hall CAS, Uhlig J (1991) Refining estimates of carbon released from tropical land-use change. Can J For Res 21(1):118-131

Haripriya GS (2000) Estimate of biomass in Indian forests. Biomass Bioenergy 19:245

Haripriya GS (2001) A frame work for carbon stored in Indian wood products. Environ Dev Sustain 3:229-251

Haripriya GS (2003) Carbon budget of the Indian forest ecosystem. Climatic Change 56:291-319

Haripriya GS, Atkinson G (2006) Accounting for India's forest wealth. Ecol Econ 59:462-476

IPCC (1995) Guidelines for greenhouse gas inventory workbook, volume 2, module 5-land use change and forestry, report prepared by UNEP, OECD, IEA and IPCC, 5.1-5.45

IPCC (2006) IPCC guidelines for national greenhouse gas inventories, prepared by the national greenhouse gas inventories programme. In: Eggleston HS, Buendia L, Miwa K, Ngara T, Tanabe $\mathrm{K}$ (eds)

Kaul M, Dadhwal VK, Mohren GMJ (2009) Land use change and net C flux in Indian forests. For Ecol Manag 258:100-108

Kauppi PE, Ausubel JH, Fang J, Mather AS, Sedjo RA, Waggoner PE (2006) Returning forests analysed with the forest identity. PNAS 103(46):17574-17579

Lal JB (1989) Indian forests, myth and reality. Nataraj Publishers, Dehradun

Lal M, Singh R (2000) Carbon sequestration potential of Indian forests. Environ Monit Assess 60:315-327

Manhas RK, Negi JDS, Rajesh K, Chauhan PS (2006) Temporal assessment of growing stock, biomass and carbon stock of Indian forests. Climatic Change 74:191-221

Ministry of Environment and Forests (1999) National forestry action programme in India. Government of India, New Delhi

Ravindranath NH, Somashekhar BS, Gadgil M (1997) Carbon flows in Indian forests. Climatic Change 35:297-320

Richards JF, Flint EP (1994) Historic land use and carbon estimates for South and Southeast Asia: 1880-1990. ORNL/CDIAC-61, NDP-046. Oak Ridge National Laboratory, Tennessee, USA, $326 \mathrm{pp}$ 